\title{
MONETARY AND FISCAL POLICY IMPLICATIONS FOR FULLJEMPLOYMENT IN NIGERIA
}

\author{
John C. Anyanwu
}

\section{INTRODUCTION}

Employment refers to the activities engaged in by persons who, during a specified period of time, work for pay or profit or are self-employed; or are unpaid workers in family business who work at least one third of normal working time; or have a job, but are not at work because of illness, industrial dispute, holiday, etc. (ILO, 1976). It is, therefore, a situation in which remuneration in cash or in kind is received in exchange for active, direct personal participation in the production process (Mouly, 1972). On the other hand, full employment obtains in a situation where everyone who wants to work at the prevailing wage rate is able to get a job; alternatively, it is a situation whereby some job seekers cannot get employment at the going wage rate but open unemployment has been reduced to a desired level (Todaro, 1977). This is akin to what McConnell and Brue (1968) call the "equilibrium or natural rate of unemployment" which can be defined variously as (a) the unemployment rate at which no excess demand or supply exists in the overall labour market, (b) the rate at which job vacancies equal the number of people unemployed or (c) the unemployment rate that will occur in the long-run if Expected and actual rates of inflation are equal. This, in no way, means zero unemployment because in every society some frictional, seasonal or voluntary and

The first version of this paper titled: "Towards Full Employment Strategy for Nigeria" was presented at the National Seminar Organized by the National Manpower Board, Lagos, in April, 1995. 


\section{Annals of The Social Science Council of Nigeria, No: 6, January-December 1994}

unavoidable involuntary ("normal") unemployment must exist (Ackley, 1978). A precise figure varies not only from time to time but also from society to society. For example, before the 1960s, normal figures ranged between 1.5 to 2 per cent; in the $1960 \mathrm{~s}$, 4 per cent was seen as normal, while in the 1970s through the 1990s, 5.5 to 6 per cent became acceptable in most nations (see also McConnell and Brue, 1986), especially as population increases. This implies not only having jobs, but also the presence of employment possibilities, sufficient employment, sufficient income, and productive employment. That is, the absence of unemployment and underemployment (see Anyanwu, 1994a).

The attainment of full employment will call for action on many fronts, of which monetary and fiscal policies are part. Monetary policy is a major economic stabilization weapon which involves measures designed to regulate and control the volume, cost, availability and direction of money and credit in an economy to achieve some specified macroeconomic policy objectives (Anyanwu, 1993a).. That means it is a deliberate effort by the monetary authorities to control the money supply and credit conditions for the purpose of achieving certain broad economic objectives. In the same vein, fiscal policy is that part of government policy concerning the raising of revenue through taxation and other means and deciding on the level and pattern of expenditure for the purpose of influencing economic activities (Anyanwu, 1993a).

The purpose of this paper is to review and analyze certain aspects of the employment problem in Nigeria arid to explore the monetary and fiscal policy implications of its solution. It is both analytic and quantitative; gloomy rather than despairing.

Thus, the remaining part of the paper is structured as follows. Section $\mathrm{n}$ provides a rough idea of the magnitude of the employment problem in Nigeria. Section in deals with a brief theoretical perspective on the monetary/fiscal policy-employment connection while section IV presents the model's framework. Section V analyzes some empirical results while the final section makes some recommendations.

\section{MAGNITUDE OF THE EMPLOYMENT PROBLEM IN NIGERIA}

Regardless of the method or approach used to measure it, unemployment in Nigeria is on a truly massive scale. This is so, in spite of the unreliability of official statistics. Table 1 shows estimates of unemployment rates from 1985 to 1993, decomposed by sector (urban and rural). Though the data show a highly fluctuating trend but two remarkable things could be 
observed: all three forms appear to be on the upward trend recently while the magnitude is higher in the urban areas than the rural areas.

Table 2 shows national unemployment rates by education level. A clearly discernible feature there is that unemployment, both national, urban and rural, is mostly among secondary school leavers. This is further confirmed by Table 3 which shows national unemployment rates by age group in 1992 and 1993. It also confirms that the large segments of unemployed Nigerians are youths. In addition, by March 1993, 17.4 per cent of those employed worked less than the 40 hours norm in the rural areas while the figure was 20.2 percent in the urban areas. Within the same period, only 67.9 per cent of those employed in the rural areas worked full time ( 0.7 per cent involuntarily out of 15.4 per cent who worked part-time) while in the urban areas 84.6 per cent worked full time per cent involuntarily out of 32.1 per cent who worked part time). 4.1 per cent of the men worked part time involuntarily while 6.1 per cent of women did so involuntarily (FOS, 1993).

Table 1:

Nigeria's Unemployment Rates 1986 -1993 (\%)

\begin{tabular}{llll}
\hline Year & National & Urban & Rural \\
1985 & 6.1 & 9.8 & 5.2 \\
1986 & 5.3 & 9.1 & 4.6 \\
1987 & 7.0 & 9.8 & 6.1 \\
1988 & 5.3 & 7.8 & 4.8 \\
1989 & 4.5 & 8,1 & 3.7 \\
1990 & 3.2 & 4.8 & 2.8 \\
1991 & 2.9 & 4.4 & 2.6 \\
1992 & 4.0 & $5 \&$ & 2.6 \\
1993 & 3.4 & $5 . S$ & 2.9
\end{tabular}

Source: CBN, Nigeria: Major Economic and Financial Indicators, April, 1994.

Thus, there are three distinct but related dimensions to the employment problem in Nigeria as indicated below:

(a) Many people are frustrated by lack of employment opportunities; they include those without work and those who have jobs but want to work longer hours or more intensively.

(b) A large fraction of the labour force, both urban and rural, lack a source of income both reliable and adequate for the basic needs of themselves and their dependants.

(c) A considerable volume of unutilized and under-utilized labour abounds in Nigeria and which ought to be brought into the employment circle. 
2 Annals of The Social Science Council of Nigeria, No: 6, January-December 1994

Table 2:

National Unemployment Rates (\%) By Educational Level Sector, 1989-1993

\begin{tabular}{lllllllllllllllll}
\hline Educational Level & \multicolumn{3}{c}{ Composite } & \multicolumn{1}{c}{ Urban } & \multicolumn{4}{c}{ Rural } \\
\hline & 1989 & 1990 & 1991 & 1992 & 1993 & 1989 & 1990 & 1991 & 1992 & 1993 & 1989 & 1990 & 1991 & 1992 & 1993 \\
\hline No Schooling & 14.8 & 13.1 & 14.1 & 15.1 & 14.3 & 13.1 & 13.3 & 16.3 & 18.8 & 15.3 & 152 & 13.0 & 13.6 & 14.3 & 14.0 \\
Primary & 24.3 & 25.4 & 17.4 & 19.9 & 21.7 & 11.6 & 16.8 & 14.4 & 14.5 & 14.3 & 27.0 & 27.3 & 18.0 & 21.0 & 23.3 \\
Secondary & 56.3 & 56.8 & 662 & 62.3 & 60.2 & 64.7 & 60.1 & 60.1 & 60.7 & 61.4 & S4..5 & 56.1 & 66.4 & 62.8 & 60.0 \\
Tertiary & 4.6 & 4.7 & 3.3 & 2.7 & 3.8 & 10.6 & 9.8 & 9.2 & 6.7 & 9.0 & 3.3 & 3.6 & 2.0 & 1.9 & 2.7 \\
\hline
\end{tabular}

Source: $\quad$ CBN,QQ1122 Annual Report and Statement of Accounts, December 1993.

Table 3:

National Unemployment Rates (\%) By Age Group, 1992 " 1993

\begin{tabular}{lllllll}
\hline , Age Group & \multicolumn{3}{l}{ Composite } & Urban & \multicolumn{2}{l}{ Rural } \\
\hline \multirow{3}{*}{15.24} & Dec. 1992 & March 1993 & Dec. 1992 & March 1993 & Dec. 1992 & March 1993 \\
\cline { 2 - 7 } 25.44 & 66.4 & 66.7 & 70.5 & 64.7 & 65.5 & 64.7 \\
45.59 & 28.2 & 25.9 & 23.5 & 24.4 & 23.4 & $26.2 "$ \\
\hline
\end{tabular}

Source: $\quad$ FOE, Statistical News, August 2,1993. 
These go to show that Nigeria's employment problem has become chronic and intractable and should be a mater of utmost national concern. Indeed, one is bound to take a gloomy view of the prospects for full employment when one considers the combination of circumstances which would be needed to reverse most or all of those trends. Taken in conjunction with the world (and local) economic recession, structural imbalance of the Nigerian industry, expanding education, and the demographic outlook for the next decade they constitute a recipe for higher levels of unemployment. Yet we cannot afford to despair. We also - ot afford to wait around - as in the 1995 budget - for the end of the world depression to solve the problem - it may not come for several years, and even if it does we may not be the beneficiaries.

\section{III}

\section{A BRIEF THEORETICAL PERSPECTIVE ON THE MONETARY/FISCAL POLICY - EMPLOYMENT CONNECTION}

The major objective of government's economic policy is to regulate the aggregate demand for goods and services which in turn, affects the level of total output. Monetary and fiscal measures are the major tools of regulation. By changing the quantity of money in circulation (monetary policy), the government can stimulate or cool down business and consumer spending. As more money is made available, consumption increases, profits rise, interest rates fall, and investment js stimulated. Conversely, as the quantity of money is reduced, money incomes rise less quickly, so that consumers spend less and funds for investment are more difficult to acquire, thus decreasing aggregate investment. Many economists such as James Duesenberry opine that monetary policy is indeed one of the set of instruments which can be used in achieving the full-employment goal. To them, the main task of monetary policy is to find a level of interest rates which exactly equates investment demand with full employment saving. For instance, the combination of consumption $(\mathrm{C})$ and governmental fiscal action $(\mathrm{G})$ will result in $\mathrm{C}+\mathrm{G}$, but it is the task of monetary policy to produce an investment (I) demand which results in the fall employment output (aggregate demand), $\mathrm{C}+\mathrm{G}+1$. This balance is the potential full employment saving of the economy. The monetary policy, therefore, is enforced to put that amount of money supply in circulation which may produce a level of interest rates which exactly equates investment demand with full employment saving (see Mithani, 1992). As Burrows and Hitiris (1978) have stated, if the money supply is raised sufficiently" in nominal terms to increase the supply of money in 


\section{Annals of The Social Science Council of Nigeria, No. 6, January-December 1994}

real terms, then the obstacle to full employment will be overcome. This increases the price level and, as the rate of interest falls, demand is stimulated to equal full employment income. However, the decline in the real rate of interest which stimulates expenditure to the full employment level requires a proportionate increase in the price level which is smaller than the proportionate increase in the nominal supply of money.

In the same vein, by changing its taxing and spending (fiscal policies), the government can change the amount of cash in the hands of consumers and adjust its own demands for goods and services. Tax increases and reduced government spending will lead to a decline in aggregate demand, while tax cuts and increased government spending will add to demand. As argued by Musgrave and Musgrave (1989), the overall level of employment in the economy depends upon the level of aggregate demand, relative to potential or capacity output valued at prevailing prices. The level of demand is a function of the spending decisions of millions of consumers, corporate managers, financial investors, and unincorporated operators. These decisions in turn depend upon many factors, such as past and present income, wealth, position, credit availability, and expectations. In any one period, the level of expenditures may be insufficient to secure full employment and restore itself automatically. Therefore, expansionary fiscal measures to raise aggregate demand are required. Thus, for example, conditions of less than full employment, increase in government expenditure, etc, will raise the price level and the rate of interest, cause a fall in the real wage rate and stimulation of supply. This eliminates the unemployment which characterized the economy in the absence of policy (see Burrows and Hitiris, 1978). Also, Keynes (1964), in his full-employment macroeconomic theory regarded fiscal policy as compensatory finance ordained to attain and maintain full employment in the economy. To pursue this goal, Keynes suggested that (a) taxation should be devised to promote and sustain consumption and investment; (b) to raise the level of effective demand and to overcome depressionary forces, the budget should be in deficit and it should have deficit financing, (c) public expenditure has to be compensatory. It has to be in a planned way to finance public works programmes and provide social security measures; (d) direct taxes should be lowered to encourage savings and investment directed towards creation of more employment opportunities; (e) public expenditure should be meant for uplifting the level of aggregate demand, investment and employment; and (f) productive borrowings should be on a large scale to finance productive public expenditure. To him, once full employment level is reached, it has to be constantly maintained by adopting appropriate fiscal measures from time to time.

One of the major reasons for regulating demand is to balance the economy's production of goods and services with consumption and, in 
turn, to generate an economic climate in which the labour needed to ; these goods and services will be fully employed. Monetary and I policies can be used to alter the level of unemployment by affecting tile demand for final products, which, in turn, changes the demand for Ubour. Arthur Okun estimated in 1962 that for every 1 per cent increase unemployment is reduced by 0.3 per cent. Though the exact figure has been modified by subsequent experience and economy in question, "Okun's Law" suggests a rather straightforward relationship between monetary and fiscal measures regulating aggregate demand and level of unemployment (Okun, 1962).

\section{IV}

\section{THE MODEL'S FRAMEWORK}

The growing body of literature now argues that the public expenditure and money stock have significant, positive effects on private sector output, productivity and capital formation and employment (see Tatom, 1991; Aschauer, 1989). Most of this literature suggests that a decline in the growth of the public expenditure and money stock causes a "productivity slump" in the private sector, lowering profitability, investment and, hence, employment (Malabre, 1990).

This public resources hypothesis is that the stock of public resources raise private sector output and employment both directly and indirectly. The direct effect arises, according to the hypothesis, because public resources provide intermediate services to private sector firms, or the marginal product of public capital services in the private sector is positive. The indirect effect arises from an assumption that public and private capital are "complements" in production - that is, the partial derivative of the marginal product of private capital services with respect to the flow of public capital services is positive. The notion of complementarity used here is known as the q-complementarity which refers to the effect of the quantity of one resource on the marginal product of another (Sato and Koizumi, 1973). Thus, a rise in public resources raises the marginal productivity of private capital services so that, given the rental price of such services, a larger flow of private capital services and a larger stock of private assets producing them are demanded. The rise in the marginal product of capital increases .private capital formation, further raising private sector output and employment.

We must note, however, that the indirect effect of a rise in public resources on private output and employment is not necessarily positive. In fact, this effect is negative if public and private capitals are substitutes. There is indeed a growing literature that suggests that government 


\section{Annuls of the Social Science Council of Nigeria, No. 6, January - December 1994}

expenditure is a substitute for private sector spending. Recent attention to this view owes much to its elaboration by Aschauer (1985) while Kormendi (1983), for example, observed that a current-period tax reduction financed by issuing government debt shifts the timing of tax collection from the current period to the future. If the future taxes implied by government debts are not fully perceived and discounted by the private sector, there will be a "net wealth effect" that increases private sector consumption, thus reducing capital accumulation, growth and employment. If, on the other hand, the implied future taxes are perceived and discounted by the private sector, the current-period tax reduction will be used to increase private saving to pay for the future taxes, and government debt will be absorbed without any real effects on the economy. Also, the effects of government expenditure financed by current-period taxation depend upon private sector perceptions. If the benefits of government expenditure are ignored, private sector consumption will fall in accordance with the reduction in permanent disposable income. To the extent that government expenditure is on consumption-type goods that are perceived as substitutes for privately provided consumption goods, there will be a relatively smaller reduction in private sector consumption.

In summary, therefore, we can identify two major channels through which government budget and money stock may affect economic performance. First, money stock and government expenditure, particularly investment, may provide goods that enter directly into private sector production, such as infrastructure and education. Money stock and government expenditure may also indirectly affect the efficiency of private sector allocation of inputs. For example, this influence will be positive to the extent that government expenditure corrects market failures, guarantees property rights and the enforcement of contracts, and provides essential public goods. In the same way, high taxes or borrowing to finance government expenditure may (distort private incentives. Also, if the financing of government investment projects bids up interest rates, private investment may be crowded out, thereby slowing growth and employment. Conversely, if public capital formation and private capital formation are truly complementary, government projects might stimulate entrepreneurs and enhance private investment, growth and employment (Lindauer and Velenchik, 1992). Since all these effects are likely to operate, the direction of the net effect becomes an empirical issue.

The second channel pertains to the efficiency of government as a producer, as distinct from a provider, of goods and services. If productivity in the public sector is lower than in the private sector, a larger public sector presence in the economy will be associated with weaker aggregate performance. However, an efficient public sector, where relative factor productivities are high will enhance aggregate output and employment. 
Differences in productivity may arise either from the nature of the goods produced or from inefficient management of the public sector relative to the private sector activities.

\section{SOME EMPIRICAL RESULTS}

To examine the hypothesis that monetary and fiscal policies influence unemployment in Nigeria, we chose money supply (Ms), lending rate (LR) and domestic credit (DC) as monetary variables, while choosing total government expenditure (GE), government capital expenditure (CAPEX), government recurrent expenditure (RECEX), company income tax (CIT), and indirect taxes (ENDT) as fiscal variables. Included in the unemployment (urban) (UN) equation are one-period lagged value of unemployment rate (UNO, gross national product (GNP), exchange rate of the naira to the U.S. dollar (ER) (external Influence), and inflation rate (INF) capturing the Philips curve trade-off. The variables are in real logarithms. The equations were estimated for the period 1975 to 1992, using ordinary least squares (OLS) in the PC-GIVE computer package (see Hendry, 1989). The data wers obtained from the Central Bank of Nigeria, Federal office of Statistics, and IMF's International Financial Statistics (1993).

The results of the estimations are presented in Table 4 . The F statistics are highly significant, allowing us to reject the null hypothesis that all explanatory variable coefficients are jointly zero. The equations' standard errors are small while the DurbinWatson (DW) Statistics show absence of any serial correlation.

The point estimates of all the parameters have the expected signs except for taxes. Important conclusions can be gleaned from the results. Given the construction of the variables, the parameters can be interpreted as elasticities.

Taken alone, none of the monetary variables (money supply, lending rate and domestic credit) significantly reduces unemployment Conversely, taken alone, all the fiscal variables (except recurrent expenditure) are highly significant in reducing unemployment;. For example, from equation (4), a one per cent increase in total government expenditure would lead to a 1.2 per cent fall in unemployment rate. From equation 5, a one per cent increase in capital expenditure results in a 77 per cent fell in unemployment rate. On the other hand, the two tax variables (company income tax and indirect taxes) have perverse signs in all the equations where they appear. In the case of company income tax, one may say that the ease with which companies in Nigeria pass on the taxes to consumers 


\section{Annals of The Social Science Council of Nigeria, No. 6, Jaruary - December 1994}

in the form of higher prices and hence make higher profits, explains the negative relationship between CIT and unemployment rate. However, as supported by Gupta (1975) indirect taxes (especially customs duties-which make up a large chunk of indirect taxes in Nigeria) act as a "protection" against foreign competition, for domestic, particularly infant, industries. This explains why the larger the customs duties, the lower tine rate of unemployment, since local industries can sell and maximize profits which is used to employ more resources through expansion. As expected, recurrent expenditure is irrelevant in employment creation.

Taken with GNP alone, the only significant monetary policy variable is the money supply - a one percent increase in money supply leads to a 2.7 per cent fall in unemployment rate (equation 9). Also, taken with GNP alone, the only significant fiscal policy variable is the company income tax - a one per cent rise in CIT results in a 1.9 per cent fall in unemployment (equation (10)). However, a combination of monetary and fiscal policies, with GNP results in a more realistic result where money supply and capital expenditure are the only significant monetary and fiscal variables respectively (equation (11)). But, it must be noted that the fiscal variable here (capital expenditure) is more important than the monetary variable (money supply). This result is consistent with Anyanwu (1993b, 1994b). This shows that fiscal policy (capital expenditure) is more effective in employment creation in Nigeria. It is also important to note that taken alone, a one per cent increase in GNP leads to a 2 per cent fall in unemployment rate.

\section{SOME RECOMMENDATIONS}

This paper has explored the magnitude of the employment problem facing Nigeria as well as the theoretical and empirical connection between the employment problem and two macroeconomic policy measures - monetary and fiscal policies The results indicate that money supply, total government expenditures, capital expenditure, company income tax, and indirect taxes are the factors influencing unemployment rate in Nigeria. The findings strongly confirm earlier findings that government expenditure (especially capital expenditure) (fiscal policy) is more effective in fighting unemployment in Nigeria. The analysis also contains a somewhat troubling finding. Unemployment in Nigeria, as indicated by the measure used in this analysis, is negatively related to company income tax (a direct tax).

Some policy implications can be gleaned from our findings. Firstly, we must reiterate that the lending rate and domestic credit, taken individually, are not relevant in the solution of the employment problem in Nigeria. It is in this light that the National Directorate of Employment's 
Monetary and Fiscal Policy Implications for Full Employment in Nigeria 11

Table 4:

OLS Regression Results of Nigeria's Urban Unemployment (UN), Monetary And Fiscal Effects, 1975-1992

\begin{tabular}{|c|c|c|c|c|c|c|c|c|c|c|c|c|c|}
\hline Independent & (1) & (2) & (3) & (4) & (5) & (6) & (7) & (8) & $(0)$ & (10) & (11) & (12) & (13) \\
\hline $\begin{array}{l}\text { Variables } \\
\text { Constant } \\
\text { UNi }\end{array}$ & $\begin{array}{l}4.950 \\
(1.337) \\
.477 * * *\end{array}$ & $\begin{array}{l}-.074 \\
(-.126) \\
.582 * *\end{array}$ & $\begin{array}{l}-.0849 \\
(-.663) \\
.694 *\end{array}$ & $\begin{array}{l}6.960 \\
(4.121) \\
.441^{*}\end{array}$ & $\begin{array}{l}4.401 \\
(4.777) \\
.372 * *\end{array}$ & $\begin{array}{l}2.474 \\
(1.117) \\
.659^{*}\end{array}$ & $\begin{array}{l}3.949 \\
(3.679) \\
.471 *\end{array}$ & $\begin{array}{l}4.712 \\
(3.009) \\
344 * * *\end{array}$ & $\begin{array}{l}20.026 \\
(7.885)\end{array}$ & $\begin{array}{l}15.850 \\
(5.648)\end{array}$ & $\begin{array}{l}9.967 \\
(5.620)\end{array}$ & $\begin{array}{l}14.968 \\
(4.707)\end{array}$ & $\begin{array}{l}17.943 \\
(6.367)\end{array}$ \\
\hline UNi & (1.939) & (2.878) & $(3.818)$ & $(3.005)$ & (2.589) & (3.569) & $(3.010)$ & (1.745) & & & & & \\
\hline \multirow[t]{2}{*}{ MS } & -.838 & & & & & & & & $991 * *$ & & $-.964 * *$ & & \\
\hline & $(-1.211)$ & & & & & & & & $(-2.679)$ & & $(-2.452)$ & & \\
\hline \multirow[t]{2}{*}{ LR } & & .293 & & & & & & & & & & & $1.388 * *$ \\
\hline & & (1.092) & & & & & & & & & & & $1-2.49 \$$ \\
\hline \multirow[t]{2}{*}{$\mathrm{DC}$} & & & .241 & & & & & & & & & & $413 * * *$ \\
\hline & & & (1.064) & & & & & & & & & & $(-2.036)$ \\
\hline \multirow[t]{2}{*}{ GE. } & & & & $-1.159 *$ & & & & & & & & & \\
\hline & & & & $(-3.870)$ & & & & & & & & & \\
\hline \multirow[t]{2}{*}{ CAPEX } & & & & & $-.769 *$ & & & & & & $-.816^{*}$ & & $1.136^{*}$ \\
\hline & & & & & H.365) & & & & & & $(-4.750)$ & & $(4.865)$ \\
\hline \multirow[t]{2}{*}{ RECEX } & & & & & & -.425 & & & & & & & \\
\hline & & & & & & $(-.909)$ & & & & & & & \\
\hline \multirow{2}{*}{ err } & & & & & & & $-1.315^{*}$ & & & $-.816^{* * * *}$ & & & $-1.127 * *$ \\
\hline & & & 4 & $\mathrm{w}$ & & & $(-3.313)$ & & & $(-1.902)$ & & & $(-2.708)$ \\
\hline \multirow[t]{2}{*}{ INDT } & & & & $i$ & & & & $-1.076^{* *}$ & & & & & \\
\hline & & & & & & & & $(-2.739)$ & & & & & \\
\hline \multirow[t]{2}{*}{ GNP } & & & & & & & & & $-2.001 *$ & $-.1 .828^{*}$ & & $-.979 *$ & \\
\hline & & & & & & & & & $(-5.154)$ & $(-3.657)$ & & $(-4230)$ & \\
\hline \multirow[t]{2}{*}{ ER } & & & & & & & & & & & & & $-.488 * *$ \\
\hline & & & & & & & & & & & & & $(-2.304)$ \\
\hline \multicolumn{14}{|l|}{ INF } \\
\hline $\mathrm{R}^{2}$ & .514 & .506 & .504 & .733 & .765 & .495 &,$\& t$ & .644 & .781 & .739 & .757 & .513 & .891 \\
\hline F-Stat. & 7.94 & 7.68 & 7.62 & 20.60 & 24.42 & 7.34 & 16.85 & 13.59 & 26.71 & 21.21 & 23.41 & 17.89 & 14.93 \\
\hline Std. Error. & .466 & .469 & .470 & .345 & .324 & .475 & .371 & .398 & .313 & .341 & .329 & .441 & .258 \\
\hline DW & 1.64 & 2.14 & 2.52 & 2.08 & 2.17 & 2.08 & 2.32 & 2.07 & 2.12 & 1.83 & 1.45 & 1.16 & 1.03 \\
\hline
\end{tabular}

Note; $\quad *$ Significant at $1 \%$ Level $\quad * *$ Sgnificant at $5 \%$ LevBl. *** Significant at $10 \%$ Level. $\quad$ a: t-Statistics are in parenthesis. Source: Author 


\section{Annals of The Social Science Council of Nigeria, No. 6, January —December 1994}

(NDE's) programmes which involve credit grants, especially the small-scale industries and graduate employment, may only be stop-gap measures, especially if taken alone. This is worsened by the fact that the intended beneficiaries of such loans pay through their noses before the meagre loans get to them.

Secondly, as a general rule, and without making fetish of a constant rate of growth, we recommend that the money supply should increase at a more or less steady rate, the exact rate being determined by the governments view of what would substitute an adequate rate of growth of GNP in current prices, to which a percentage point or two should be added to take account of the growing monetization of the Nigerian economy.

Thirdly, in order to tackle the employment problem in Nigeria, we must ensure that aggregate demand is sufficient to absorb whatever labour can be employed with the existing capital stock For example, a tax structure which maximizes the volume of employment must be put in place - and this is one that encourages investment and growth, and at the same time produces elastic revenues for labour-intensive government projects. The most obvious measure to take is to immediately eliminate all labourdisplacing capital subsides which hitherto had made capital cheap and labour dear, thus, encouraging entrepreneurs to mechanize production. Therefore, import duty reliefs on some agricultural and industrial machinery as well as other capital goods whose consequence is capital-intensive production should be immediately discontinued and the revenues saved from there should be used to fund "industrial parks ${ }^{11}$ and "trading houses" for labour-intensive small-scale industries. At the same time, import duties on most of such machinery and other capital goods should be raised. Apart from promoting labourintensive production and creating employments, this measure will aiso encourage local capital goods production. Also, duties on luxury goods, which tend to be produced with imported inputs by capital-intensive methods should be raised.

Fourth, there is an urgent need for long-term, low cost, group specific net employment creation measures (see McCarthy, 1981). The main limitation of current approaches/measures is that its originate IB assumed that employment creation would only need to be temporary or short term. In effect, their originators never realized that unemployment in Nigeria is a long-term phenomenon which is unlikely to bottoms out. We are therefore suggesting the discarding of all current comforting illusions. What is needed now is a recognition of the need for more permanent employment creation, providing work for a significant proportion of the total labour force. Having made this point, it should not be necessary to say why costs will have to be carefully considered. This is not the place to debate the case for and against existing levels of government expenditure or the presumed effect of moving to much higher levels. Suffice to say that 
the government has to reduce its expenditure on defence, which has been very high over the years, and divert more of the funds to new capital expenditure for employment creation. While it may be difficult to determine the upper limit of defence expenditure, it is much easier to set a minimum rate of employment to which Nigerians ought to be entitled. Indeed, the example of a superpower like the U.S. tends to indicate that the sky is the limit to defence expenditure. That is understandable, given that all the basic needs and unemployment security have been adequately catered for. It is thus unlikely that any Nigerian would want to be so adequately protected against an "imagined" external aggression only to die of hunger and disease, emanating from lack of job because the government could not provide the necessary financial resources needed for such job creation.

Again the need for employment creation to be group-epecific derives from the uneven distribution of unemployment rates in Nigeria. Help must be concentrated on the youth and new entrants to the labour market - notably young workers in the areas of unusually high unemployment.

But employment creation in Nigeria needs to be group-specific in another sense as well. It is one way of trying to deal with the supply imbalance of the Nigerian labour market This means that the employment created, so far as possible, ought to be those that are in notable short supply - most crucially in export industries, or areas of the economy where there is a strong "public interest" case of expanding existing services and facilities (such as health and basic education). Also, if employment creation is to survive as more or less permanent and expanding feature of the Nigerian economy, it must be possible to defend it from the charge of being just another form of concealed subsidy: this means that the employment created must be "new" or additional to those that would have existed without employing creation through increased government capital expenditure.

An Employment Generation Fund should be established through revenue earmarking, especially from revenue realized from increases in the prices of petroleum products. This will help to apply the benefit principle of revenue generation while resulting in more assurance of minimum levels of financing full employment creation (thus avoiding periodic haggling within the bureaucracy), and greater stability and continuity of funding full employment creation (McCleary, 1991, Schwarz and Volgy, 1988). The greater chunk of this should be channelled to the development of the informal sector (especially small-scale farming) which holds great potential for employment creation in Nigeria.

In addition, the government should establish "enterprise zones" (to be managed by enterprise boards) with greater governmental presence through land acquisition and investment in infrastructural facilities (see Davies and Metcalf, 1985). 


\section{Annals of The Social Science Council of Nigeria, No. 6, January-December 1994}

This will further encourage private sector investments in new companies/enterprises, thus fostering greater cooperation between government and the private sector in combating joblessness in Nigeria

Though this paper addresses the monetary cum fiscal dimensions of the attainment of full employment in Nigeria; but given its multidimensional nature, other measures must complement these monetary and fiscal measures. Such measures include checking rapid population explosion (not only through legislation but also through mass education, economic incentives and disincentives); checking rural-urban migration (through integrated rural development, social investments aimed at raising rural incomes, and the spread of small-scale industries throughout the countryside); executing a more functional educational system that ensures a balanced skill development and national manpower requirements so as to create opportunities not only for wage employment but also for self-employment; and encouraging the establishment of many small-scale, labourintensive industries (through direct investments and incentives to the private sector).

In a sense, public debate about the problems of unemployment in Nigeria would centre on this kind of discussion. Analysts and economists would take up different positions arguing for their favoured "mix" of solutions. Others would decide that we could not afford to do anything much about the problem of long-term employment creation because it is too expensive. But, at least, the rest of us would know the cost of refusing to accept this inhuman and divisive doctrine, while the opponents must also reconcile themselves to accepting higher levels of unemployment for the foreseeable future.

\section{REFERENCES}

Ackley, G (1978), Macroeconomics Theory and Polity. Hong Kong; Collier - Macmillan.

Anyanwu, J. C. (1993a): Monetary Economics: Theory, Policy and Institutions. Onitsha: Hybrid Publishers Ltd.

(1993b): "The Effects of Monetary and Fiscal Policies Under Rational Expectations: The Nigerian Case, 1970 1988." Unpublished Ph.D Thesis, Department of Economics, University of Ibadan, 311pp.

(1994a): "Labour Force Characteristics: Measurement of Employment, Unemployment and Underemployment." Paper Presented at-the National Training Workshop on Manpower and Employment Planning Techniques and Methodologies, Organized by the National Manpower Board at Lagos, Akure, Minna, and Owerri. 
Monetary and Fiscal Policy Implications for Full Employment in Nigeria 15

(1994b): "Fiscal Neutrality and Unemployment in Nigeria: Some Econometric Eesults". African Journal of Economic Policy, Vol. 1, No. 2, December, 89 - 99.

Aschauer, D. A (1983) "Fiscal Policy and Aggregate Demand." American Economic Review, March, 117 -127.

(1989): "Does Public Capital Crowd Out Private Capital?" Journal of Monetary Economics, September, 171 -188.

Burrows, P. and Hitiris, T (1978): Macroeconomic Theory: A Mathematical Introduction. Chichesten John Wiley \& Sons.

Central Bank of Nigeria (1993): Annual Report and Statement of Accounts. Lagos, December. (1994): Nigeria: Major Economic and Financial Indicators. Lagos, April.

Davis G. and D. Metcalf (1985): Generating Jobs: The Cost-Effectiveness of Tax Cuts, Public Expenditure, and Special Employment Measures in Cutting Unemployment. London: Simon Coates.

Federal Office of Statistics (1993): Statistical News, August 2.

Feldstein, M and D. W. Elmendorf (1990): "Government Spending and Private Sector Behaviour Revisited: Comment." American Economic Review, June, 589 - 599.

Gupta A P. (1975): "Public Finance and Employment: The Indian Case." International Labour Review, Vol. 112, No. 4, October 279 - 290.

Hendry D. F. (1989): PC-GIVE: An Interactive Econometric Modeling System. University of Oxford.

ILO 1976): International Recommendations on Labour Statistics. Geneva: ILO.

IMF (1993): International Financial Statistics Yearbook, 1993.

KEYNES, J. M. (1964): General Theory of Employment, Interest and Money. New YorkHarcourt, Brace and World.

Lindauer, D. L and A D. Velenchik (1992): "Government Spending in Developing Countries: Trends, Causes, and Consequences". The World Bank Research Observer, Vol. 7, No. 1, January, 59 - 78. 
16 Annals of The Social Science Council of Nigeria, No. 6, January-December 1994

Malabre, A L (1990): "Economic Roadblock: Infrastructure Neglect." Wall Street Journal, July 30 .

McCarthy W. (1981): "What Can We Do About Unemployment?" Industrial Relations Journal, Vol. 12, No. 6, November/ December, 5-9.

McCleary W. (1991): "The Earmarking of Government Revenue: A Review of Some World Bank Experience". The World Bank Research Observer, Vol. 6, No. 1, January, 81 -104.

McConnell C.R and S. L Brue (1986): Contemporary Labour Economics. New York McGrawHill.

Mithani D. M (1992): Money, Banking, International Trade and Public Finance. Bombay: Himalaya Publishing House.

Modigiiani, F and A G Sterling (1990): "Government Debt, Government Spending and Private Sector Behaviour A Further Comment" American Economic Review, June, 600 - 603.

Mouly J (1972: "Some Remarks on the Concepts of Employment, Underemployment and Unemployment" International Labour Review, Vol. 105, Jan - June, 155 -160.

Musgrave R. A and P. B Musgrave (1989): Public Finance in Theory and Practice. New York: McGraw-Hill.

Okun A (1962): "Potential GNP: Its Measurement and Significance". Proceedings of the Business and Economic Statistical Association, 98-104.

Sato, R and T Koizumi (1973): "On the Elasticities of Substitution and Complementary." Oxford Economic Papers, March, 44-56.

Schwarz J. E. and T. J Volgy (1988): "Experiments in Employment - A British Cure". Harvard Business Review, Vol. 66, Ma. 2, March/ April, 104-112.

Tatom, J. A (1991): "Public Capital and Private Sector Performance" Federal Reserve Bank of St. Louis Review, Vol. 73, No. 3,3 -15.

Taylor, C.T (1979): "Crowding Out: Its Meaning and Significance. "InS. T. Cook and P. M. Jackson, (eds). Current Issues in Fiscal Policy: Martin Robertson, 86 -107.

Todaro, M. P (1977): Economics for a Developing World. Hong Kong; Longman. 